\title{
PENAPISAN AKTIVITAS AMILOLITIK DAN ANTIBAKTERI DARI BAKTERI SEDIMEN PERAIRAN PULAU LEMUKUTAN
}

\author{
Nora Idiawati, Kristina Adelita, Mega Sari Juane Sofiana \\ Jurusan IImu Kelautan, Fakultas Matematika dan IImu Pengetahuan Alam, \\ Universitas Tanjungpura, Pontianak, Indonesia \\ E-mail : noraidiawatisrg@gmail.com \\ Received February 2019 , Accepted April 2019
}

\begin{abstract}
ABSTRAK
Resistansi bakteri saat ini menjadi permasalahan dalam bidang kesehatan. Hal ini dikarena meningkatnya Multiple Drug Resistance (MDR) oleh bakteri patogen. Oleh karena itu, perlu dilakukan penelitian mengenai sumber senyawa antibakteri, salah satunya dari bakteri pada sedimen laut. Tujuan dari penelitian ini adalah untuk mengetahui aktivitas antibakteri pada bakteri sedimen laut dari Perairan Pulau Lemukutan. Isolasi bakteri dari bakteri sedimen laut diperoleh sebanyak 4 isolat. Penapisan aktivitas antibakteri dilakukan dengan metode cross streak. Bakteri patogen yang digunakan adalah Eschericia coli, Staphylococcus aureus, Vibrio cholerae, Pseudomonas aeruginosa, dan Salmonela typhimurium. Aktivitas antibakteri terbaik diperoleh pada bakteri SKA04 dapat menghambat bakteri patogen $S$. typhimurium. Penapisan aktivitas enzim ekstraseluler dilakukan untuk mengetahui potensi isolat bakteri sedimen laut dalam menghasilkan enzim amilolitik dan lipase. Uji aktivitas ezim amilolitik diperoleh 3 isolat menghasilkan enzim amilolitik yaitu SKA02, SKA03 dan SKA04 yang ditandai dengan terbentuknya zona bening di sekitar koloni bakteri.
\end{abstract}

Kata kunci : Amilolitik, Antibakteri, Bakteri Sedimen Laut, Lemukutan

\section{ABSTRACT}

\begin{abstract}
AMYLOLYTIC AND ANTIBACTERIAL ACTIVITIES ASSESSMENT OF SEDIMENTARY BACTERIA OF LEMUKUTAN ISLAND. Bacterial resistance is currently a complication in the health sector. This is due to receiving several resistance drugs (MDR) by pathogenic bacteria. Therefore, it is necessary to do research on antibacterial sources, one of which is from bacteria in marine sediments. The purpose of this study was to study the antibacterial activity of marine sedimentary bacteria from Lemukutan Island. The isolation of bacteria from marine sediment bacteria obtained 4 isolates. Screening of antibacterial activity was carried out using the cross streak method. The pathogenic bacteria used are Escherichia coli, Staphylococcus aureus, Vibrio cholerae, Pseudomonas
\end{abstract}


aeruginosa, and Salmonela typhimurium. The best antibacterial activity obtained in SKAO4 bacteria can inhibit pathogenic bacteria $S$. typhimurium. Screening of extracellular enzyme activity was carried out to determine the potential of marine sediment bacteria isolates in producing amylolytic enzymes and lipases. The amylolytic enzyme activity test obtained 3 isolates which produced amylolytic enzymes, namely SKA02, SKAO3 and SKAO4 which were characterized by the formation of clear zones around bacterial colonies.

Keywords : Amylolytic, Antibacterial, Marine Sedimentary Bacteria, Lemukutan

\section{PENDAHULUAN}

Resistansi bakteri saat ini menjadi permasalahan dalam bidang kesehatan dimana antibiotik sudah tidak efektif lagi melawan bakteri patogen. Hal tersebut terjadi karena meningkatnya multiple drug resistance (MDR) oleh bakteri patogen (Saha et al., 2014; Chang et al., 2015; Thirumalairaj et al., 2015). Bakteri patogen yang telah resistan memerlukan senyawa antibakteri baru yang dapat membunuh atau menghambat pertumbuhannya. Senyawa antibakteri dapat diperoleh dari bakteri sedimen laut. Bakteri sedimen laut dilaporkan telah menghasilkan isolat yang memiliki aktivitas antibakteri dan antijamur (Jafarzade et al., 2013; Dalisay et al., 2013; Claverias et al., 2015).

Beberapa penelitian mengenai bakteri sedimen laut penghasil senyawa antibakteri telah banyak dilakukan. Sekhar et al (2012) melaporkan sebanyak 6 isolat dari 23 isolat sedimen laut di India menunjukkan aktivitas antibakteri terhadap Escherichia coli, Pseudomonas aeruginosa, Proteus vulgaris, Bacillus cereus, Bacillus subtilis and Staphylococcus aureus. Bacillus sonorensis MT39 menghasilkan Sonoresin yang memiliki aktivitas antibakteri terhadap Listeria monocytogenes dan Staphylococcus aureus (Chopra et al., 2015).

\section{MATERI DAN METODE}

Penelitian ini dilaksanakan pada bulan Mei 2017 hingga Oktober 2018. Pengambilan sampel sedimen diambil di Perairan Pulau Lemukutan. Pengambilan sampel sedimen menggunakan SCUBA. Sampel sedimen diambil $130 \mathrm{~m}$ dari pantai pada kedalaman $5 \mathrm{~m}$. Sampel sedimen diambil dengan menggunakan botol falcon steril. Sampel dimasukkan ke dalam cool box sebelum dianalisis di laboratorium.

Sampel sedimen ditimbang sebanyak $1 \mathrm{~g}$. Sampel kemudian di suspensi dalam air laut steril $45 \mathrm{~mL}$ dan diencerkan hingga $10^{-4}$. Sampel bakteri hasil pengenceran $10^{-2}-10^{-4}$ diambil masing-masing $100 \mu \mathrm{l}$ dan ditumbuhkan pada media agar dengan metode tuang dan di inkubasi selama 5 hari pada suhu $37^{\circ} \mathrm{C}$. Morfologi koloni bakteri yang terbentuk diamati diameter, warna, bentuk, elevasi, serta tepian koloni. 
Uji aktivitas antibakteri dilakukan dengan metode cross streak. Koloni isolat bakteri sedimen ditumbuhkan dengan cara menggoreskannya di tengah petri dan diinkubasi selama 24 jam pada suhu $37^{\circ} \mathrm{C}$, selanjutnya bakteri uji ditumbukan tegak lurus pada isolat bakteri sedimen dan di inkubasi selama 48 jam pada suhu $37^{\circ} \mathrm{C}$. Aktivitas antibakteri ditandai dengan adanya zona hambat di sekitar isolat.

\section{HASIL DAN PEMBAHASAN}

\section{Isolasi Bakteri}

Pengambilan sampel sedimen dilakukan pada tanggal 7 Mei 2017 di Perairan Pulau Lemukutan. Hasil isolasi dari bakteri sedimen di peroleh sebanyak 4 isolat. Berdasarkan hasil pengamatan morfologinya diperoleh koloni dengan perbedaan diameter, warna, bentuk, tepian, dan elevasi (Tabel 1).

Hasil isolasi yang diperoleh selanjutnya dilakukan uji aktivitas antibakteri dan uji aktivitas enzim amilolitik dan lipase dengan melihat zona bening yang terbentuk pada isolat bakteri sedimen (Gambar 1 dan Gambar 2).

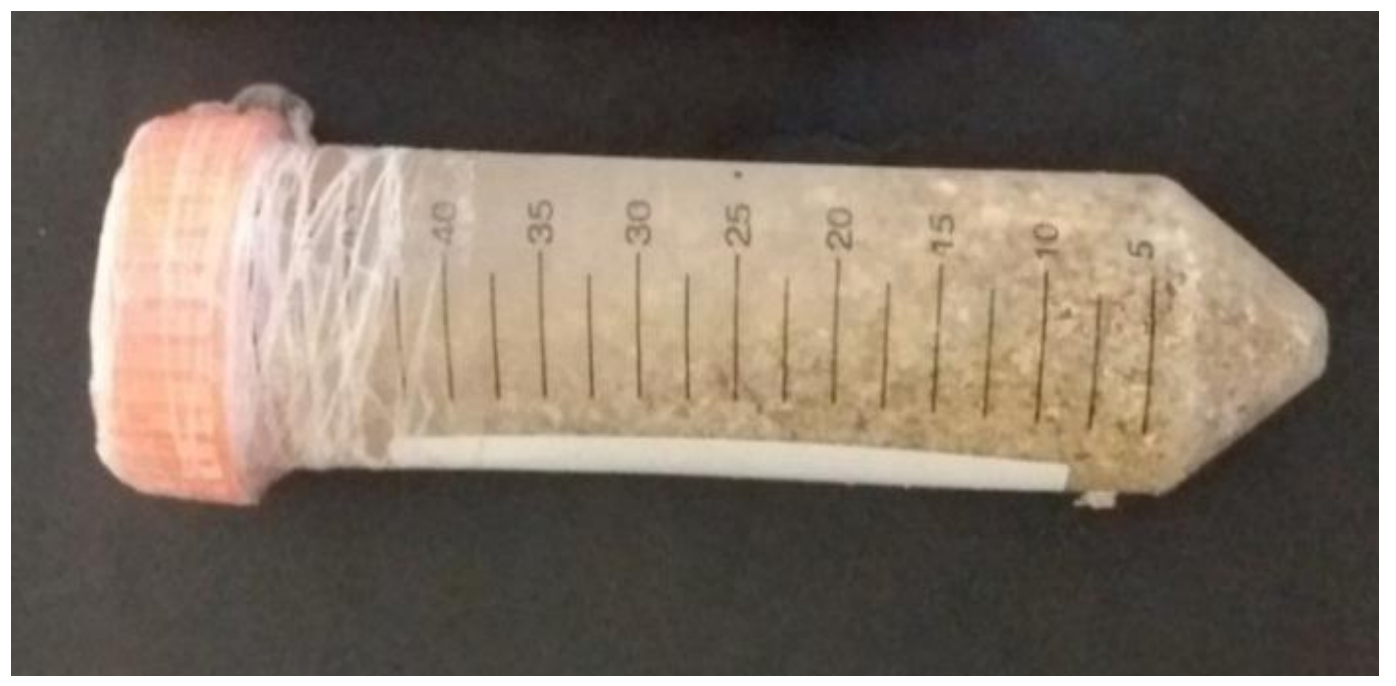

Gambar 1. Sampel sedimen laut

Tabel 1. Morfologi Koloni Isolat Bakteri Sedimen

\begin{tabular}{llllll}
\hline $\begin{array}{l}\text { Kode } \\
\text { Bakteri }\end{array}$ & $\begin{array}{l}\text { Diameter } \\
(\mathrm{mm})\end{array}$ & Warna & Bentuk & Elevasi & Tepian \\
\hline SKA01 & 0,48 & Putih & Bulat & Datar & Bergelombang \\
SKA02 & 0,69 & Putih & Bulat & Cembung & Bergelombang \\
SKA03 & 1,42 & Putih & Bulat & Datar & Bergerigi \\
SKA04 & 0,41 & Putih & Bulat & Datar & Bergerigi \\
\hline
\end{tabular}




\section{Aktivitas Antibakteri}

Hasil uji aktivitas antibakteri bakteri sedimen laut diperoleh 4 isolat. Satu diantaranya menunjukkan aktivitas antibakteri yang ditandai dengan adanya zona bening (Tabel 2). Isolat bakteri sedimen laut tidak menunjukan adanya aktivitas antibakteri pada media tumbuhnya. Hal tersebut disebabkan karena media tumbuh yang mengandung cukup nutrisi bagi pertumbuhan bakteri sehingga metabolit sekunder tidak terbentuk. Isolat bakteri sedimen tersebut ditumbuhkan ke media Zobell mengandung zat penginduksi berupa glukosa dan gliserol. Penambahan senyawa penginduksi pada media tumbuh dapat meningkatkan aktivitas antibakteri pada isolat bakteri. Senyawa penginduksi merupakan prekursor yang dibutuhkan isolat untuk menghasilkan senyawa yang memiliki aktivitas antibakteri (Lygo dan Wainwright, 1997).

Hasil menunjukan aktivitas antibakteri setelah ditambahkan senyawa penginduksi terdapat pada isolat SKA04 yang dapat mengahambat bakteri uji $S$. typhimurium glukosa yang ditandai dengan terbentuknya zona bening pada koloni bakteri (Gambar 2). Zona bening terbentuk dari hasil ekskresi senyawa dengan aktivitas antibakteri. Senyawa antibakteri tersebut dihasilkan dari metabolit sekunder. Metabolit sekunder terbentuk apabila terjadi penurunan kecepatan pertumbuhan, penambahan senyawa penginduksi dan keterbatasan ketersedian nutrisi (Demain, 1998).

Tabel 2. Uji Aktivitas Antibakteri Sedimen Laut

\begin{tabular}{|c|c|c|c|c|c|}
\hline \multirow{2}{*}{ Media } & \multirow{2}{*}{ Bakteri Uji } & \multicolumn{4}{|c|}{ Isolat Bakteri } \\
\hline & & SKA01 & SKA02 & SKA03 & SKA04 \\
\hline \multirow[t]{5}{*}{ NA } & E. coli & - & - & - & - \\
\hline & $P$. aeruginosa & - & - & - & - \\
\hline & S. typhimurium & - & - & - & - \\
\hline & S. aureus & - & - & - & - \\
\hline & V. cholerae & - & - & - & - \\
\hline \multirow[t]{5}{*}{ M13 } & E. coli & - & - & - & - \\
\hline & P. aeruginosa & - & - & - & - \\
\hline & S. typhimurium & - & - & - & - \\
\hline & S. aureus & - & - & - & - \\
\hline & V. cholerae & - & - & - & - \\
\hline \multirow[t]{5}{*}{ Zobell } & E. coli & - & - & - & - \\
\hline & $P$. aeruginosa & - & - & - & - \\
\hline & S. typhimurium & - & - & - & - \\
\hline & $\begin{array}{l}\text { S. aureus } \\
\text { V. cholerae }\end{array}$ & - & - & - & - \\
\hline & & - & - & - & - \\
\hline
\end{tabular}




\begin{tabular}{|c|c|c|c|c|c|}
\hline \multirow{2}{*}{ Media } & \multirow{2}{*}{ Bakteri Uji } & \multicolumn{4}{|c|}{ Isolat Bakteri } \\
\hline & & SKA01 & SKA02 & SKA03 & SKA04 \\
\hline \multirow[t]{5}{*}{$Z^{-1}$} & E. coli & - & - & - & - \\
\hline & $P$. aeruginosa & - & - & - & - \\
\hline & S. typhimurium & - & - & - & - \\
\hline & S. aureus & - & - & - & - \\
\hline & V. cholerae & - & - & - & - \\
\hline \multirow[t]{5}{*}{$Z^{-1} A$} & E. coli & - & - & - & - \\
\hline & P. aeruginosa & - & - & - & - \\
\hline & S. typhimurium & - & - & - & + \\
\hline & S. aureus & - & - & - & - \\
\hline & V. cholerae & - & - & - & - \\
\hline \multirow[t]{5}{*}{$Z^{-1} B$} & E. coli & - & - & - & - \\
\hline & $P$. aeruginosa & - & - & - & - \\
\hline & S. typhimurium & - & - & - & - \\
\hline & S. aureus & - & - & - & - \\
\hline & V. cholerae & _- & _- & _- & _- \\
\hline Ketera & $\begin{array}{l}Z^{-1}, Z^{-1} A \text { (Zobe } \\
\text { Positif (+) (terbe } \\
\text { zona bening) }\end{array}$ & $\begin{array}{l}Z^{-1} B( \\
\text { ening) }\end{array}$ & $\begin{array}{l}- \\
\text { beell } \\
\text { egat }\end{array}$ & $\begin{array}{l}\text { serol) } \\
\text { (tidak }\end{array}$ & - \\
\hline
\end{tabular}

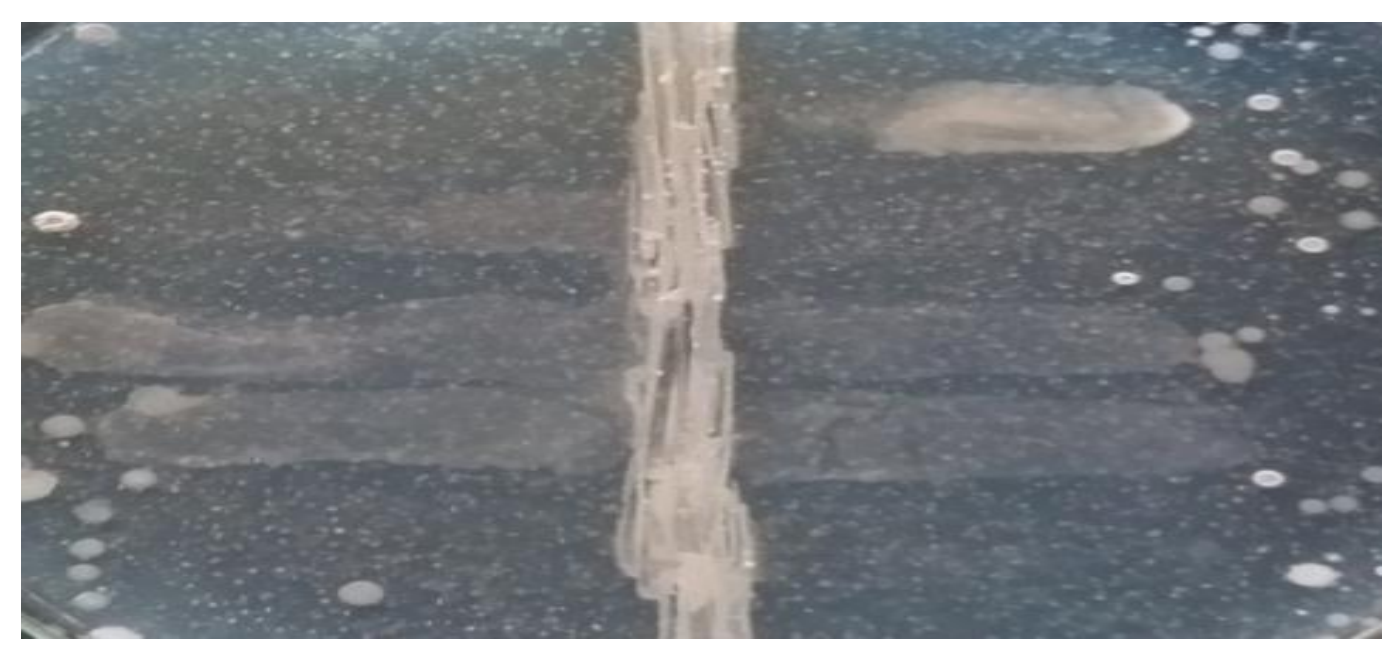

Gambar 2. Uji Aktivitas Antibakteri

\section{Aktivitas Enzim}

Isolat bakteri sedimen laut selanjutnya diuji aktivitas enzimnya untuk mengetahui aktivitas enzimatis isolat bakteri sedimen laut dengan uji amilolitik dan lipase. Hasil uji aktivitas enzim diperoleh 3 isolat yang berpotensi menghasilkan enzim amilolitik (Tabel 3). Amilase merupakan enzim ekstraseluler yang dikeluarkan oleh bakteri untuk menghidrolisis pati yang ada di luar sel. Hasil hidrolisis diserap kembali ke dalam sel oleh 
bakteri dan digunakan sebagai sumber energi, berkembang biak, dan cadangan nutrisi (Kaneko et al, 2005).

Tabel 3. Hasil Seleksi Heterofik Berdasarkan Kemampuan Lipase Bakteri Sedimen Laut

\begin{tabular}{cc}
\hline \multirow{2}{*}{ Isolat } & Isolat Bakteri \\
\cline { 2 - 2 } & Lipase \\
\hline SKA01 & - \\
SKA02 & - \\
SKA03 & - \\
SKA04 & - \\
\hline
\end{tabular}

\section{KESIMPULAN}

Isolat bakteri sedimen laut yang memiliki aktivitas antibakteri yaitu SKA04 yang mampu menghambat pertumbuhan bakteri patogen $S$. typhimurium. Berdasarkan hasil identifikasi isolat bakteri sedimen laut diperoleh genus Oceanospirillum, Pseudomonas, dan Methylophaga.

\section{UCAPAN TERIMA KASIH}

Penulis mengucapkan ucapan terima kasih kepada Pemerintah Daerah Kabupaten Sekadau dan Community Development \& Outreaching Universitas Tanjungpura yang telah memberikan beasiswa penuh Satu Dusun Satu Sarjana (SDSS) sehingga penulis dapat menyelesaikan studi di FMIPA Untan.

\section{DAFTAR PUSTAKA}

Chang; Han H.; Cohen T.; Grad Y. H.; Hanage W. P.; O'brien T. F. and Lipsitch M., 2015, Origin and Proliferation of Multiple-Drug Resistance in Bacterial Pathogens, J. Mmb., 79:101-116.

Chopra L.; Singh G.; Jena K. K. and Sahoo D. K., 2015, Sonorensin: A New Bacteriocin with Potential of an Anti-Biofilm Agent and a Food Biopreservative, Scientific Reports., 5:1-41.

Claverias F. P.; Barrena A. U.; González M.; Seeger M. and Cámara B., 2015, Culturable Diversity and Antimicrobial Activity of Actinobacteria from Marine Sediments in Valparaíso Bay, Chile, Frontiers in Microbiol., 6:737. 
Dalisay D. S.; Williams D. E.; Wang X. L.; Centko R.; Chen J. and Andersen R. J., 2013, Marine Sediment-Derived Streptomyces Bacteria from British Columbia, Canada are a Promising Microbiota Resource for the Discovery of Antimicrobial Natural Products, Plos One., 8: E77078.

Demain A. L., 1999, Pharmaceutically Active Secondary Metabolites of Microorganisms, Appl Microbio., 52:455-463.

Jafarzade M.; Yahya N. A.; Mohamad S.; Usup G. and Ahmad A., 2013, Isolation and Characterization of Pigmented Bacteria Showing Antimicrobial Activity from Malaysian Marine Environment, Malaysian J of Microbiology., 9: 152-160.

Kaneko T., Ohno T., and Ohisa A., 2005, Purification and Characterization of a Themostable Raw Starch Digesting Amylase from a Streptomyces sp. Isolated In a Milling Factory, J. Bioscience Biotechnology. Biochemistry., 6:1073-1081.

Lygo B., and Wainwright P. G., 1997, Biosynthetic Induction of a Secondary Metabolites by a Marine Bacterium Under Nutrionak Stress: Potential Role of the Incomplete Oxidation of an organic acid, Bioll Bull., 193:274-275.

Saha A.; Das R.; Dasgupta M.; Dutta S.; Haque G. and Mitra A. K., 2014, Isolation and Characterization of Multi Drug Resistant Pathogen from Soil Samples Collected from Hospital Disposal Site, J. of Environmental Science, Toxicology and Food Technology., 8:74-80.

Sekhar G. A. D. M. C.; Krishna E. R.; Kumar P. S. and Mohanc C. M., 2012, Isolation and Screening of Antimicrobial Activity of Marine Sediment Bacteria from Bay of Bengal Coast, Visakhapatnam, $J$ of Pharmacy Research., 5:1318-1319.

Thirumalairaj J.; Shanmugasundaram T.; Sivasankari K.; Natarajaseenivasan K. and Balagurunathan R., 2015, Isolation, Screening and Characterization of Potent Marine Streptomyces sp. Pm105 Against Antibiotic Resistant Pathogens, Asian $J$ of Pharmaceutical and Clinical Research., 8:439-443. 